\title{
Laju Respirasi, Pertumbuhan, dan Sintasan Benih Ikan Mas (Cyprinus carpio) Dikultur Pada Berbagai Salinitas
}

\section{Respiration Rate, Growth, and Survival Rate of Carp (Cyprinus carpio) Fry Cultured on Various Salinities}

\author{
Syamsu Alam ${ }^{1}$, Andi Adam Malik ${ }^{1 *}$ dan Khairuddin ${ }^{1}$ \\ ${ }^{1}$ Program Studi Budidaya Perairan, Fakultas Pertanian, Peternakan dan Perikanan, Universitas \\ Muhammadiyah Parepare, Jl. Jenderal Ahmad Yani, Soreang, Pare-Pare 91112, Indonesia
}

*Correspondence :
andiadammalikhamzah@yahoo.
co.id

Received : 2019-12-20

Accepted : 2020-02-25

\section{Kata Kunci :}

Laju respirasi, Pertumbuhan, Sintasan, Cyprinus carpio,

\section{Salinitas}

\section{Keywords :}

Respiration rate, Growth, Survival rate, Cyprinus carpio, Salinity

\begin{abstract}
Abstrak
Penelitian ini bertujuan untuk mengetahui pengaruh salinitas yang berbeda terhadap laju respirasi, pertumbuhan, dan sintasan ikan mas. Benih ikan mas sebagai sampel dengan panjang $3 \mathrm{~cm}$ yang diproduksi oleh Balai Benih Ikan Karrang dengan padat tebar 20 ekor $/ \mathrm{m}^{2}$ dengan kadar protein pakan $36 \%$ dengan dosis $20 \%$ dari biomassa. Salinitas dibuat dengan menambahkan garam pada media kultur dengan empat jenis perlakuan salinitas dan 3 kali ulangan. Laju respirasi tertinggi pada perlakuan D dan terendah pada A. Pertumbuhan berat pada minggu 1 seragam, selanjutnya minggu 2 mulai bervariasi. Laju pertambahan bobot tertinggi didapatkan pada perlakuan B (1,77 gram/hari). Sintasan benih ikan mas tertinggi pada perlakuan A (96\%) dan terendah pada perlakuan D (60\%) yang secara umum semakin menurun dengan bertambahnya waktu penelitian. Konsentrasi salinitas media kultur yang optimal untuk pemeliharaan benih ikan mas yaitu $4 \mathrm{ppt}$.
\end{abstract}

\footnotetext{
Abstract

This study aims to determine the level of salinity that has an optimal effect on the rate of respiration, growth, and survival of carp. Carp seeds samples with 3-5 cm length produced by Karrang Hatchery with stocking densities of 20 individuals $/ \mathrm{m}^{2}$. The feed used is a commercial feed containing $36 \%$ protein with a dose of $20 \%$ of body weight. Salinity is made by adding salt to the culture media with four types of salinity treatment and three replications. Respiration rate is highest at treatment $\mathrm{D}$, and lowest at A. Weight growth at week one was uniform, then week 2 starts to vary. The highest weight gain rate was obtained in treatment $\mathrm{B}$ (1.77 grams/days). The salinity concentration of culture media significantly affected the survival of carp seeds. The optimal salinity concentration of culture media for the maintenance of carp seeds is $4 \mathrm{ppt}$.
} 


\section{PENDAHULUAN}

Potensi luas areal budidaya air payau saat ini tercatat 2.964.331 Ha, dengan tingkat pemanfaatan $650.509 \mathrm{Ha}$ (21,9\%).

Tambak udang Indonesia mencapai 380.000 hektar dan sekitar 75\% masih dikelola secara tradisional (Suyanto dan Takarina, 2009). Provinsi Sulawesi Selatan memiliki luas areal pertambakan \pm 87.000 hektar dari potensi lahan seluas 150.000 hektar. Luas lahan ini menunjukkan bahwa potensi lahan yang ada belum dimanfaatkan secara optimal (Dinas Perikanan dan Kelautan Provinsi Sulawesi Selatan, 2018).

Guna menjamin produksi yang optimal, target produksi ikan pada tahun 2019 yaitu 18,8 juta ton (KKPRI, 2017), maka diperlukan ketersediaan sarana dan prasarana produksi. Penggunaan tambak ini untuk membudidayakan spesies ikan air tawar adalah sangat mungkin asalkan ikan dapat mentolerir kondisi salin.

Ikan mas (Cyprinus carpio Linn) merupakan salah satu dari 10 jenis ikan air tawar penting yang dibudidayakan di Indonesia Ikan mas merupakan salah satu jenis ikan konsumsi yang mempunyai nilai ekonomis penting (Saparinto, 2010; Boyd, 1982; Tobin dan Dusheck, 2005).

Laporan Kinerja Direktorat Jenderal

Perikanan Budidaya Tahun 2014 melaporkan bahwa perkembangan produksi ikan mas mengalami peningkatan produksi rata-rata dari tahun $2010-2014$ sebesar $14,44 \%$, begitu pula dengan angka nilai produksi selama kurun waktu yang sama menunjukkan kenaikan rata-rata per tahun sebesar 18,67\%.

Pertumbuhan ikan mas tergolong cepat karena pada umur 5 bulan sejak telur menetas bibitnya sudah mencapai 500 g/ekor (Cahyono, 2000). Sedangkan kecepatan pertumbuhan ikan mas di kolam biasanya $3 \mathrm{~cm}$ setiap bulan (Susanto, 2006). Iwama et al. (1997) menyatakan laju konsumsi oksigen ikan mas (Cyprinus carpio) adalah sebesar $0,14 \mathrm{ml} / \mathrm{g} / \mathrm{jam}$ saat inaktif, dan 0,255 $\mathrm{ml} / \mathrm{g}$ saat aktif. Hal ini dikarenakan pada saat aktif, sel-sel tubuh memerlukan lebih banyak energi dan karena itu lebih banyak oksigen (Ashraf et al., 2010; Foss et al., 2001; Fujaya, 2002; Abdel-Hakim et al., 2008; Sumeru dan Anna, 1992; Saravanan et al., 2018; Saputra et al., 2017).

Berdasarkan hal tersebut, maka dipandang perlu melakukan kajian mengenai laju respirasi, pertumbuhan dan sintasan benih ikan mas (Cyprinus carpio Linn) yang dikultur pada berbagai salinitas. Tujuan penelitian ini adalah untuk mengetahui pengaruh salinitas yang berbeda terhadap laju respirasi, pertumbuhan, dan sintasan ikan mas. Sedangkan keterbaharuannya adalah sebagai salah satu bahan informasi mengenai kadar salinitas yang optimal untuk budidaya ikan mas.

\section{METODOLOGI}

\section{Waktu dan Tempat}

Penelitian ini dilaksanakan selama 3 bulan mulai bulan Maret sampai Mei 2018 di Balai Benih Ikan (BBI) Karrang Desa Karrang Kecamatan Cendana Kabupaten Enrekang.

\section{Materi Penelitian}

Alat yang digunakan adalah baskom plastik bulat volume 30 liter (sebagai media hewan uji), ember plastik 10 liter sebagai tempat pemberian pakan, timbangan elektrik tipe DS-671 merek DIGI kapasitas hingga $30 \mathrm{~kg}$ (sebagai alat untuk menimbang pakan), $\mathrm{pH}$ meter Nutron. Tech $\mathrm{pH}-0,09-\mathrm{A}$, pen type $\mathrm{pH}$ meter buatan Cina (untuk mengukur $\mathrm{pH}$ air), tes kit (untuk mengukur amonia), DO meter spesifikasi DO-5509 Lutron : range $0-20 \mathrm{mg} / \mathrm{L}$ buatan Taiwan untuk mengukur $\mathrm{O}_{2}$ dan suhu, hand refractometer V SA1 Salinity 0 - 100 0/00 size $27 \quad x 40 \quad x \quad 190$ buatan Cina (mengukur salinitas), handcounter merek Joyko HC 4 D 0 - 9.999 hitungan buatan Cina, dan stop watch menggunakan 
aplikasi pada Samsung Tablet A6 (untuk menghitung respirasi pada ikan).

\section{Rancangan Penelitian}

Rancangan yang digunakan adalah Rancangan Acak Lengkap (RAL) 4 jenis perlakuan salinitas dengan 3 kali ulangan. Kadar salinitas perlakuan didasarkan hasil penelitian Saputra et. al. (2017) sebagai berikut: Perlakuan A salinitas $0 \mathrm{ppt}$; perlakuan B salinitas 4 ppt; perlakuan C salinitas $8 \mathrm{ppt}$, dan perlakuan D salinitas $12 \mathrm{ppt}$.

\section{Prosedur Kerja}

Kadar salinitas dibuat dengan menambahkan garam curah (tidak beryodium) pada media kultur sesuai dengan perlakuan yang dicobakan. Wadah yang digunakan dalam penelitian ini adalah baskom kapasitas $30 \mathrm{~L}$ yang diisi air sebayak $20 \mathrm{~L}$. Wadah penelitian tersebut ditempatkan secara acak di dalam kolam guna menjaga fluktuasi suhu media kultur. Penelitian ini dilakukan dengan beberapa tahapan, yaitu sebelum digunakan terlebih dahulu dicuci dengan detergen, kemudian dibilas dengan air bersih lalu dikeringkan.

Media kultur yang digunakan terlebih dahulu diendapkan selama 3 hari dan ditampung pada bak fiber glass volume $1000 \mathrm{~L}$. Setelah itu dimasukkan ke dalam wadah kultur dengan volume masing-masing 20 L, selanjutnya ditambahkan garam sesuai dengan salinitas yang diinginkan.

Sebelum dilakukan penebaran benih, ikan uji terlebih dahulu diadaptasikan secara bertahap, dimana setiap perbedaan 2 ppt diadaptasikan selama 15 menit (Kandjou, 2008). Sesaat setelah penebaran benih dilakukan pengamatan laju respirasi awal pada 5 ekor sampel pada setiap unit percobaan, dengan menghitung frekuensi bukaan operkulum selama 2 menit (Ratningsih, 2008).

Selama proses pemeliharaan dilakukan pergantian air setiap hari sebanyak $10 \%$ dari total volume. Sampling populasi dan pengukuran panjang dan laju respirasi serta parameter kualitas air dilakukan setiap minggu.

Parameter kualitas air yang diamati selama penelitian berupa suhu, $\mathrm{pH}, \mathrm{CO}_{2}$, $\mathrm{O}_{2}$, salinitas, dan amonia. Data yang diperoleh dalam penelitian ini akan ditampilkan dalam bentuk grafik dan tabulasi.

\section{Analisis Data}

Parameter penelitian yang diamati yaitu laju respirasi, laju pertumbuhan panjang spesifik, sintasan, dan parameter kualitas air. Pengaruh perlakuan dianalisis menggunakan sidik ragam (ANOVA) dan dilanjutkan Uji Lanjut Tukey guna mengetahui perbedaan pengaruh antar perlakuan (Singgih, 2000). Sebagai alat bantu yang digunakan SPSS versi 21.0 for Windows, sedangkan untuk penyajian grafik dan tabulasi data menggunakan Microsoft Excel 2007.

Laju respirasi diukur dengan menghitung frekuensi bukaan operkulum per satuan waktu (Ratningsih, 2008) sebagai berikut:

$\mathrm{Lr}=\sum \frac{\mathrm{f}}{\mathrm{t}}$

Keterangan :

Lr : Laju respirasi

f : Frekuensi bukaan operkulum

t : Waktu (Menit)

Laju pertumbuhan panjang spesifik (LPPS) menggunakan rumus Effendie (1979) yang dimodifikasi sebagai berikut: Lpps $=\frac{\mathrm{Pk}-\mathrm{PA}}{\mathrm{t}}$

Keterangan :

Lpps : Laju Pertumbuhan Panjang Spesies

$\mathrm{Pk} \quad$ : Panjang Akhir $(\mathrm{cm})$

PA : Panjang Awal $(\mathrm{cm})$

$\mathrm{T} \quad$ : Waktu penelitian (hari)

Sintasan dalam penelitian ini dihitung berdasarkan rumus Effendie (1979) sebagai berikut:

$\mathrm{S}=\frac{\mathrm{Nt}}{\mathrm{No}} \times 100 \%$

Keterangan :

$\mathrm{S} \quad$ : Sintasan (\%)

Nt : Jumlah Hewan Uji pada akhir (Ekor)

No : Jumlah Hewan Uji pada awal (Ekor) 


\section{HASIL DAN PEMBAHASAN}

\section{Pertumbuhan Berat}

Analisis ragam dan uji lanjut Tukey menunjukkan bahwa laju pertumbuhan benih ikan mas yang dikultur pada berbagai salinitas tidak berpengaruh nyata $(\mathrm{P}>0,05)$ terhadap pertumbuhan berat benih ikan mas. Pertumbuhan berat pada minggu pertama relatif seragam, selanjutnya pada minggu kedua mulai bervariasi. Hal tersebut disebabkan oleh penggunaan energi masih sedikit terutama dalam pembentukan sel somatik sehingga pertambahan bobot cenderung seragam. Sedangkan pada minggu kedua hingga akhir penelitian pengaruh faktor nutrisi menjadi penting dimana penundaan pemberian pakan mempengaruhi pertambahan bobotnya.
Laju pertambahan bobot tertinggi didapatkan pada perlakuan B sebesar 1,744 g/hari (Gambar 1). Hasil ini sesuai dengan penelitian Syandri (2018) bahwa berat rata-rata Osphronemus gouramy pada salinitas $12 \mathrm{ppt}$ dan tertinggi secara signifikan pada salinitas 4 ppt. Sintasan tertinggi diperoleh pada 4 ppt diikuti oleh 0 ppt, 8 ppt dan 12 ppt salinitas.

Salinitas yang lebih tinggi pertumbuhan cenderung lebih lambat pada awal penelitian, hal tersebut disebabkan oleh adaptasi lingkungan yang ekstrem sehingga lebih banyak energi yang diperlukan untuk proses osmoregulasi dibandingkan pertumbuhan somatik. Saputra et al. (2017) mendapatkan laju pertumbuhan berat dan panjang benih ikan mas ras Wildan pada salinitas $5 \mathrm{ppt}$ masing-masing sebesar 1,41 g/hari dan $0,49 \mathrm{~cm} /$ hari.

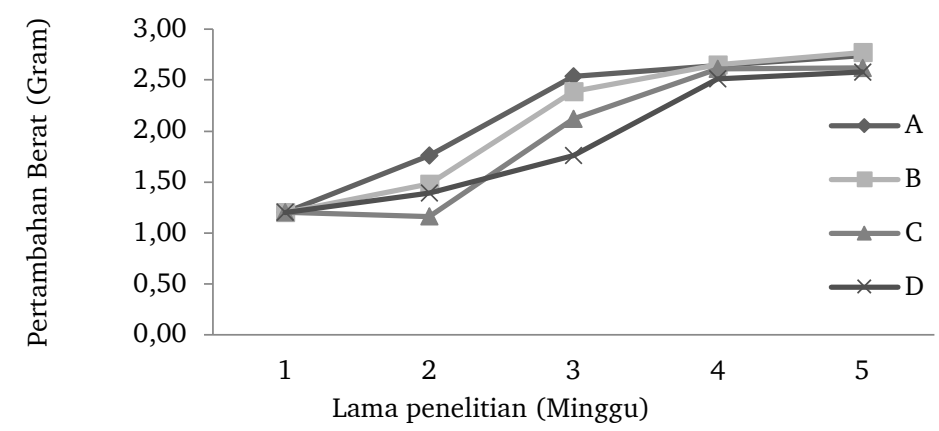

Gambar 1. Pertumbuhan berat benih ikan mas selama penelitian.

\section{Pertumbuhan Panjang}

Hasil analisis ragam dan uji lanjut Tukey pada panjang benih ikan mas menunjukkan bahwa laju pertambahan panjang benih ikan mas yang dikultur pada berbagai salinitas tidak berbeda nyata $(\mathrm{P}>-0,05)$ antar perlakuan terhadap pertumbuhan panjangnya.

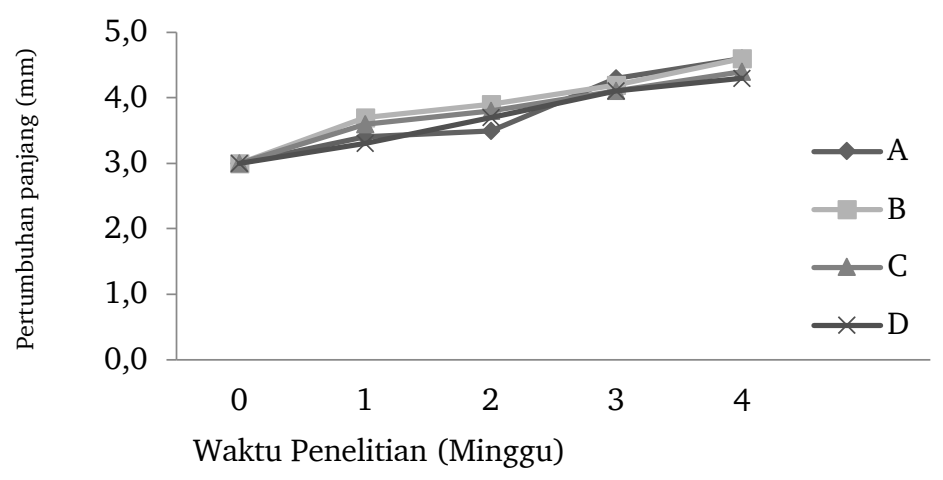

Gambar 2. Laju pertambahan panjang benih ikan mas pada berbagai perlakuan selama penelitian. 
Dari Gambar 2 terlihat bahwa pertumbuhan panjang meningkat dari minggu pertama hingga akhir penelitian (minggu ke-4). Laju pertumbuhan panjang tertinggi didapatkan pada perlakuan A dan B dengan nilai 1,7777 g/hari. Pertambahan panjang berkaitan dengan perkembangan struktur tulang belakang.

\section{Sintasan}

Hasil analisis ragam (ANOVA) dan uji lanjut Tukey, menunjukkan bahwa konsentrasi salinitas media kultur berpengaruh nyata terhadap sintasan benih ikan mas $(\mathrm{P}<0,05)$. Uji lanjut Tukey menunjukkan perlakuan $\mathrm{A}, \mathrm{B}$, dan
$\mathrm{C}$ tidak berbeda nyata $(\mathrm{P}>0,05)$, sedangkan perlakuan $\mathrm{D}$ berbeda nyata dengan perlakuan lainnya $(\mathrm{P}<0,05)$.

Dari Gambar 3 terlihat sintasan benih ikan mas semakin menurun dengan bertambahnya waktu penelitian, dimana sintasan terendah didapatkan pada perlakuan D yaitu $60 \%$ dan tertinggi pada perlakuan B sebesar 96\%. Hal tersebut disebabkan oleh tingginya penggunaan energi untuk mempertahankan kelangsungan hidupnya sehingga kebutuhan untuk regenerasi sel tidak terpenuhi yang pada akhirnya menyebabkan tingkat kematian yang tinggi.

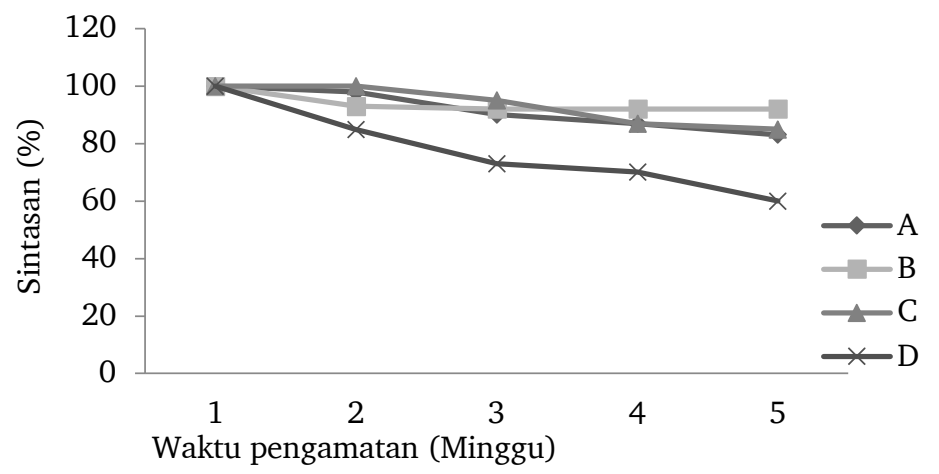

Gambar 3. Sintasan benih ikan mas selama penelitian.

Benih ikan mas memerlukan sedikit kadar garam dalam media hidupnya dimana kondisi ideal adalah 4 ppt. Konsentrasi ini dapat memberikan kondisi keseimbangan pada tekanan osmotik sehingga energi yang digunakan untuk mempertahankan cairan tubuhnya lebih sedikit, dan lebih banyak digunakan untuk pertumbuhan jaringan. Alava (1998) menyebutkan bahwa salinitas secara langsung akan mempengaruhi kehidupan organisme dalam laju pertumbuhan, jumlah makanan yang dikonsumsi, nilai konversi makanan dan sintasan. Selanjutnya Laiz-Carrión et al. (2005) menyatakan bahwa perubahan salinitas dapat menyebabkan perubahan laju metabolisme. Lebih lanjut dijelaskan bahwa ikan-ikan yang berukuran sedang lebih tahan terhadap perubahan salinitas daripada ikan berukuran kecil. Setiap spesies mempunyai kisaran salinitas optimal yang dapat ditolerir. Kenaikan salinitas yang terlalu tinggi akan mengakibatkan tekanan osmotik air meningkat dan kematian akan tinggi.

\section{Laju Respirasi}

Hasil analisis ragam dan uji lanjut Tukey menunjukkan bahwa salinitas media kultur berpengaruh nyata $(\mathrm{P}<0,05)$ terhadap laju respirasi ikan. Perlakuan A dan B tidak berbeda nyata $(\mathrm{P}>0,05)$, tetapi berbeda nyata dengan perlakuan $C$ dan D $(P<0,05)$. Dari Gambar 4 terlihat laju respirasi tertinggi didapatkan pada perlakuan $\mathrm{D}$ dan terendah pada perlakuan A. Hal tersebut disebabkan oleh peningkatan kebutuhan oksigen untuk mencapai keseimbangan fisiologis pada awal fase adaptasi. Setelah benih beradaptasi, kebutuhan oksigen 
relatif sama pada berbagai tingkatan salinitas.

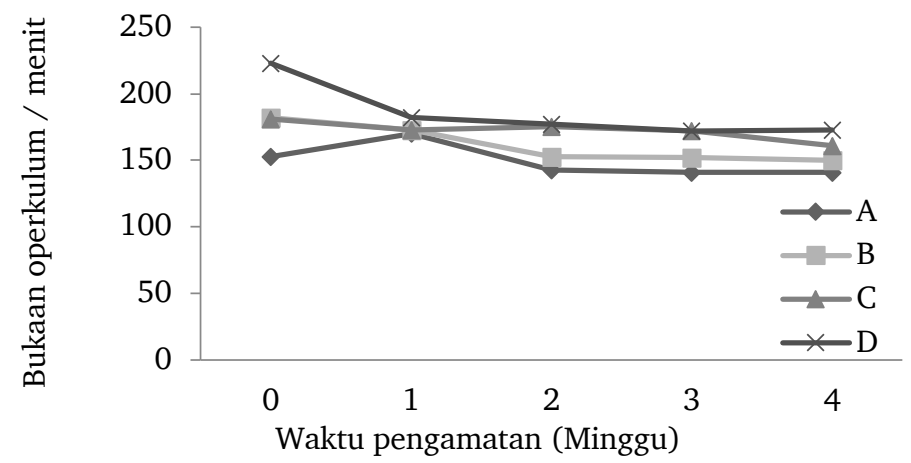

Gambar 4. Laju respirasi (bukaan operkulum/menit) pada berbagai salinitas benih ikan mas selama penelitian.

\section{Kualitas Air}

Amri dan Khairuman (2005) menyatakan bahwa $\mathrm{pH}$ air antara 5-11 dapat ditoleransi oleh ikan mas. Suhu yang terukur selama penelitian berkisar antara $28-29^{\circ} \mathrm{C}$ (Tabel 1). Kisaran suhu tersebut tergolong masih sesuai dan baik untuk budidaya ikan mas. Hal ini sesuai dengan pendapat Makaminan (2011), bahwa kisaran suhu optimum bagi kehidupan ikan adalah antara $25-32^{\circ} \mathrm{C}$, sedangkan menurut Kordi dan Tancung (2007) adalah $28-32^{\circ} \mathrm{C}$.

Suhu merupakan faktor penting dalam proses metabolisme dan kelarutan oksigen. Fluktuasi suhu pada budidaya tergolong kecil karena aktivitas pompa yang menyirkulasi air dari wadah pemeliharaan ke media filtrasi dan kembali ke wadah pemeliharaan. Suhu merupakan salah satu faktor yang mempengaruhi nafsu makan ikan mas (Jaja et al., 2013) dan mempengaruhi kadar oksigen terlarut (DO) dalam air.

Arie (2007) menyatakan bahwa derajat keasaman $(\mathrm{pH})$ mempengaruhi daya produktivitas suatu perairan. Air yang bersifat basa dan netral cenderung lebih produktif dibandingkan dengan air yang bersifat asam. Nilai $\mathrm{pH}$ yang dapat ditolerir antara 5-11, tetapi kehidupan normal pada $\mathrm{pH}$ antara 7-8 (Asnawi, 1983). Hasil penelitian diperoleh bahwa nilai pH pada kisaran 7,6-8,3. Hasil tersebut tergolong baik untuk budidaya ikan mas. Nilai $\mathrm{pH}$ yang baik untuk budidaya ikan mas berkisar 6,5-8,5 (Wihardi et al., 2015).

Kadar amonia yang terukur berkisar 0,002-0,006 mg/L. Amonia dapat muncul secara alami atau diproduksi (Silaban dan Santoso, 2012). Amonia cenderung meningkat seiring dengan peningkatan salinitas. Rendahnya kadar amonia yang terukur selama penelitian disebabkan oleh penggantian air secara rutin dan didukung oleh sistem aerasi yang baik. Menurut Fazil et al. (2017), nilai standar amonia yang diperbolehkan dalam budidaya ikan yaitu 0,5 mg/L, sedangkan menurut Widiastuti (2009), ikan mas mulai terganggu pertumbuhannya apabila air media hidupnya mengandung amonia sebesar $1,2 \mathrm{mg} / \mathrm{L}$.

Tabel 1. Hasil pengukuran kualitas air selama penelitian.

\begin{tabular}{ccccc}
\hline \multirow{2}{*}{ Parameter } & \multicolumn{4}{c}{ Perlakuan } \\
\cline { 2 - 5 } & A & B & C & D \\
\hline Suhu $\left({ }^{\circ} \mathrm{C}\right)$ & $28-29$ & $28-29$ & $28-29$ & $28-29$ \\
Amoniak (mg/L) & 0,002 & 0,005 & 0,005 & 0,006 \\
pH & $7,6-7,9$ & $7,6-8,2$ & $7,6-8,3$ & $7,6-8,3$ \\
Oksigen Terlarut(mg/L) & $4,6-5,7$ & $4,6-5,3$ & $4,6-5,2$ & $4,6-5,2$ \\
Karbon dioksida (mg/L) & 10 & 15 & 10 & 12 \\
Salinitas (ppt) & 0 & 4 & 8 & 12 \\
\hline
\end{tabular}

Keterangan : A : 0 ppt, B : 4 ppt, C : 8 ppt, D : 12 ppt 
Larva ikan mas yang hidup dalam konsentrasi oksigen rendah sulit makan sehingga pertumbuhannya melambat, dan jika berlangsung lama maka akan berhenti makan. Jika kandungan oksigen terlarut dalam media pemeliharaan tidak optimal, ikan mas akan membuka mulutnya dan berada di permukaan air, bahkan bila air tidak segera diganti dapat menimbulkan kematian. Kadar oksigen terlarut di perairan atau di kolam yang baik bagi pertumbuhan ikan mas yaitu $>4 \mathrm{mg} / \mathrm{L}$ (Wihardi et al., 2015). Kisaran oksigen yang terukur selama penelitian 4,6 - 5,7 mg/L. Kisaran tersebut masih dalam kondisi yang optimal untuk pertumbuhan dan sintasan benih ikan mas. Karbon dioksida $\left(\mathrm{CO}_{2}\right)$, yang terukur yaitu sekitar 8-15 mg/L. Kadar $\mathrm{CO}_{2}$ yang tinggi didapatkan pada perlakuan $\mathrm{B}$ hal tersebut disebabkan oleh populasi ikan yang lebih banyak.

\section{KESIMPULAN}

Berdasarkan uraian yang telah dikemukakan, dapat ditarik beberapa kesimpulan bahwa konsentrasi salinitas media kultur berpengaruh nyata terhadap sintasan dan laju respirasi, tetapi tidak berpengaruh terhadap pertumbuhan benih ikan mas. Selain itu, konsentrasi salinitas media kultur yang optimal untuk pemeliharaan benih ikan mas yaitu 4 ppt.

\section{UCAPAN TERIMA KASIH}

Peneliti mengucapkan terima kasih kepada Balai Benih Ikan Karrang atas dukungan dan bantuan menyelesaikan riset ini. Penelitian ini juga tidak akan dapat terlaksana tanpa komitmen dan kerja keras dari seluruh tim.

\section{DAFTAR PUSTAKA}

Abdel-Hakim, E., Gamal, E., Zeinab, A. dan Greisy, E., 2008. Effect of removal of eggs adhesiveness on hatchability and effect of different levels of salinity on survival and larval development in common carp Cyprinus carpio. Journal of Applied Sciences, 4(12), pp. 1935-1945. http://www.aensiweb.com/old/jasr /jasr/2008/1935-1945.pdf.

Alava, V.R., 1998. Effect of salinity, dietary lipid source and level on growth of milkfish (Chanos chanos) fry. Aquaculture, 167(3-4), pp.229236. https://doi.org/10.1016/ S0044-8486(98)00317-2.

Amri, K. dan Khairuman, 2005. Budi daya Ikan Nila secara intensif. AgroMedia, Jakarta. p.144.

Arie, U., 2007. Pembenihan \& pembesaran Nila Gift. Penebar Swadaya, Bogor.

Ashraf, M., Bengtson, D.A. dan Simpson, K.L., 2010. Development of salinity stress tests for larval striped bass, Morone saxatilis and inland silversides, Menidia beryllina, used in nutritional studies. Pakistan Journal of Nutrition, 9(6), pp.616623. http://dx.doi.org/10.3923/ pjn.2010.616.623.

Asnawi, S., 1983. Memelihara ikan dalam keramba. PT. Gramedia, Jakarta. p.81.

Boyd, C.E., 1982. Water quality management for pond fish culture. Elsevier Scientific Publishing Co. p.318.

Cahyono, B., 2000. Budidaya ikan air tawar: Ikan Gurami, Ikan Nila, Ikan Mas. Penerbit Kanisius, Jakarta. p. 111.

Dinas Perikanan dan Kelautan Provinsi Sulawesi Selatan, 2018. Laporan statistik perikanan Sulawesi Selatan. Dinas Perikanan dan Kelautan Provinsi Sulawesi Selatan. Makassar.

Effendie, M.I., 1979. Biologi perikanan. Yayasan Dewi Sri, Bogor. p.112.

Fazil, M., Adhar, S. dan Ezraneti, R., 2017. Efektivitas penggunaan ijuk, jerami padi dan ampas tebu sebagai filter air pada pemeliharaan ikan mas koki (Carassius auratus). Acta Aquatica: Aquatic Sciences Journal, 4(1), pp.37-43. https://doi.org/10. 29103/aa.v4i1.322.

Foss, A., Evensen, T.H., Imsland, A.K. dan Øiestad, V., 2001. Effects of reduced salinities on growth, food 
conversion efficiency and osmoregulatory status in the spotted wolffish. Journal of Fish Biology, 59(2), pp.416-426. https:// doi.org/10.1111/j.1095-8649.2001. tb00140.x.

Fujaya,Y., 2002. Fisiologi Ikan : dasar pengembangan teknologi perikanan. Departemen Pendidikan Nasional, Jakarta. p.204.

Iwama, G.K., Takemura, A. dan Takano, K., 1997. Oxygen consumption rates of tilapia in fresh water, sea water, and hypersaline sea water. Journal of Fish Biology, 51(5), pp.886-894. https://doi.org/10. 1111/j.1095-8649.1997.tb01528.x.

Jaja, Suryani, A. dan Sumantadinata, K., 2013. Usaha pembesaran dan pemasaran ikan lele serta strategi pengembanganya di UD Sumber Rezeki Parung, Jawa Barat. Manajemen IKM, 8(1), pp.45-56. https://doi.org/10.29244/mikm.8. 1.45-56.

Kandjou, K., 2008. Effect of salinity on oxygen consumption and growth of juvenile white steenbras, Lithognathus lithognathus (Doctoral dissertation, Rhodes University).

Kementerian Kelautan dan Perikanan Republik Indonesia, 2017. Peraturan Menteri Kelautan Dan Perikanan Republik Indonesia Nomor : 63/Permen-Kp/2017 Tentang Rencana Strategis Kementerian Kelautan Dan Perikanan Tahun 2015-2019.

Kordi, M.G.H. dan Tancung, A.B., 2007. Pengelolaan kualitas air dalam budidaya perairan. Rineka Cipta, Jakarta. p.210.

Laiz-Carrión, R., Sangiao-Alvarellos, S., Guzmán, J.M., del Río, M.P.M., Soengas, J.L. dan Mancera, J.M., 2005. Growth performance of gilthead sea bream Sparus aurata in different osmotic conditions: implications for osmoregulation and energy metabolism. Aquaculture, 250(3-4), pp.849-861. https://doi.org/10.1016/j.aquacult ure.2005.05.021.

Makaminan, W., 2011. Studi parameter kualitas air pada lokasi budidaya ikan di Danau Tondano Desa Eris Kecamatan Eris Kabupaten Minahasa Provinsi Sulawesi Utara. Skripsi. Fakultas Perikanan Dan Ilmu Kelautan, Universitas Sam Ratulangi Manado.

Ratningsih, N., 2008. Uji toksisitas molase pada respirasi ikan mas (Cyprinus carpio L.). J Biotika, 6(1), pp.22-33.

Saparinto, C. 2010. Usaha ikan konsumsi lahan $100 \mathrm{~m}^{2}$. Penebar Swadaya, Jakarta. p.171.

Saputra, A., Praseno, O., Sudradjat, A. dan Prasetio, A.B., 2017. Pertumbuhan beberapa strain ikan mas yang dipelihara pada tambak bersalinitas rendah. In Prosiding Forum Inovasi Teknologi Akuakultur (pp. 79-86). http://ejournalbalitbang.kkp.go.id/index.php/fita/ article/view/6349/5327.

Saravanan, M., Ramesh, M., Petkam, R. dan Poopal, R.K., 2018. Influence of environmental salinity and cortisol pretreatment on gill $\mathrm{Na}+/ \mathrm{K}+-$ ATPase activity and survival and growth rates in Cyprinus carpio. Aquaculture reports, 11, pp.1-7. https://doi.org/ 10.1016/j.aqrep.2018.04.002.

Silaban, T.F. dan Santoso, L., 2012. Pengaruh penambahan zeolit dalam peningkatan kinerja filter air untuk menurunkan konsentrasi amoniak pada pemeliharaan ikan mas (Cyprinus carpio). e-Jurnal Rekayasa dan Teknologi Budidaya Perairan, 1(1), pp.47-56. https:// dx.doi.org/10.23960/jrtbp.v1i1.104 p47-56.

Singgih, S., 2000. Buku latihan SPSS statistik parametrik. PT. Elex Media Komputindo, Jakarta.

Sumeru, S.U. dan Anna, S., 1992. Pakan udang windu (Penaeus monodon). Penerbit Kanisius, Jakarta. p.93. 
Susanto. H., 2006. Budidaya ikan di pekarangan. Penebar Swadaya, Jakarta.

Suyanto, S.R. dan Takarina, E.P., 2009. Panduan budidaya udang windu. Penebar Swadaya, Jakarta. p.116.

Syandri, H., 2018. Effects of Salinity on survival and growth of gurami sago (Osphronemus goramy, Lacepède, 1801) Juveniles. Pakistan journal of biological sciences: PJBS, 21(4), pp.171-178. https://doi.org/10. 3923/pjbs.2018.171.178.

Tobin, A.J. dan Dusheck, J., 2005. Asking about life. Brooks/Cole-Thomson Learning, Belmont. p.879.

Widiastuti, I.M., 2009. Pertumbuhan dan kelangsungan hidup (survival rate) ikan mas (Cyprinus carpio) yang dipelihara dalam wadah terkontrol dengan padat penebaran yang berbeda. Media Litbang Sulteng, 2(2), pp.126-130. http://jurnal. untad.ac.id/jurnal/index.php/MLS/ article/download/58/51.

Wihardi, Y., Yusanti, I.A. dan Haris, R.B.K., 2015. Feminisasi pada ikan mas (Cyprinus carpio) dengan perendaman ekstrak daun-tangkai buah Terung Cepoka (Solanum Torvum) pada lama waktu perendaman berbeda. Jurnal Ilmu-Ilmu Perikanan dan Budidaya Perairan, 9(1), pp. 23-28. https://jurnal. univpgri-palembang.ac.id/index.

php/ikan/article/download/338/13 47. 